\title{
Designing Character for Bandung Tourism Campaign
}

\author{
Devi Kurniawati Homan \\ Visual Communication Design \\ School of Design \\ Bina Nusantara University \\ Jakarta, Indonesia \\ dhoman@binus.edu \\ Aris Darisman \\ Visual Communication Design \\ School of Design \\ Bina Nusantara University \\ Jakarta, Indonesia \\ adarisman@binus.edu
}

\begin{abstract}
Bandung is the capital of west java province in Indonesia. It was referred to Paris van Java because of the beauty. Nowadays, since access to the city of Bandung is easier both domestically and international, Bandung become the travel destination. Like other travel destination in Indonesia, Bandung known as shopping and culinary tourism destination. To differentiate Bandung with other destination city in Indonesia, it need a differentiator that will help to characterize the city. A character design that used as a soft tourism campaign is needed. It will become the ambassador to persuade the target market to come and love Bandung as a city tourism destination. First of all, mascot will be a good way to represent and branding the city. The mascot should be developed to represent a culture and positive image of the city and become the pride for its citizens. Object of this study was Cepot from wayang golek Sunda. The Research covers visual aspects, philosophical and ideological. Every character designs are influenced by the culture. Each culture has different visual traditions with different ideological backgrounds. The best approach before make a character design, is to recognize the character design in every culture. How a culture affect the human figure and its visual style and the living creatures. The character culture can be found in its design history, anatomy and story. It become the basis of the new character creation.
\end{abstract}

Keywords—wayang golek, cepot, tourism, character design, ambassador

\section{INTRODUCTION}

Game, Campaign, Movie and most of TV program rely on the character to deliver information. It become the main ambassador to persuade the target market to try or continue on their main content of information. When we talk about campaign, we talk about the message to be communicated. An icon become the most powerful thing to deliver the messages. As it is when we talk about destination campaign. Bandung city is a capital town of West Java. It located $140 \mathrm{~km}$ from Jakarta the capital city of Indonesia. Since the Cipularang highway is opened in 2005, Bandung became the main destination for weekend gateway. Especially from the tourist from Jabodetabek and when the airlines budget opened the route to Bandung from the foreign country and the other cities of Indonesia, Bandung became more popular for tourism destination. Bandung is flodded with the tourist from neighbour countries. Like the others cities of indonesia who known for the shopping and culinaire for the tourist destination. It leads to intense competition for tourism industry. Bandung needs to differentiate it self from others to attract more visitor, increase tourism and foreign investment. With integrated and designed campaign it expected to increase the tourism industry. The connection from the messenger to the audience need to built for the good bonding between them. When the bonding become powerful and personal it will be easy to deliver the messages to the audience. Mascot or character is one of the main part for making a personal bonding between the audience and the messsenger. The character will become the ambassador to communicate all the message, information and be the diferentiator from the other campaign all at once. The main thing is, that character should be represent the good imagery of the city and become the pride for its citizen.

\section{Character Study}

West Java province is home for Sundanese culture. Sundanese is one of largest ethnic culture in Indonesia after Java. Although it located in the Java island, West Java is different from Central Java and East Java. The culture and language is quite different, even though they are also related in many ways. Tourism is closely related in culture. West Java itself is known for the Sundanese culture. Besides shadow puppet which known from Central and East Java, there is wayang golek from Sundanese puppet show. The show is very popular and well known among the people of West Java.

Wayang golek can be differentiate in two. There is Wayang golek papak (Cepak) and wayang golek purwa. wayang golek are played by a puppeteer which known in Indonesian language as dalang. He is the leader of the show. Based on the story and the gamelan music, it can be differentiated between wayang golek papak and wayang golek purwa. Wayang golek purwa is playing the Mahabarata story with gamelan music in salendro rhythmic. While wayang golek papak is playing epics story such as Arya Jipang, Jaka Tingkir or the other action story with gamelan music in pelog rhythmic.

The character in wayang golek basically same with the character from shadow puppet. The characters are from 
Ramayana and Mahabarata story with additional of Punakawan as the supporting and the adviser of the main character. Semar still believed to be an important figure in wayang golek, he is a picture of gentleman, smart and wise as the behavior of the god who incarnate as human. There is another character in wayang golek which has a lot of fans. He is Bagong who known as Bawor, Carub, Sastrajingga or Cepot. In Pacitan, Cepot known as Mangundiwagsa, while in East Java he known as Besut. There are lot of versions about the birth of Cepot. The first is, Cepot is birth from the shadow of God it self, in other word Cepot is birth from the shadow of Semar, who ask for a companion to his father, when he is going to incarnate as human. Semar don't like to be alone, beside he need a witness for every task he need to complete. His father told him to look back, suddenly there is someone just looked like him. Pug nose, big eyes and wide mouth. The other story is state that Cepot is the first born of three siblings from Semar and Sutiragen. Other story Cepot was born from a hut. Anyways, whatever the story of how Cepot was born, he always describe as the same character. He is a humorous and sarcasm person. His words is annoying yet funny, he always talk logically and full of joke. It doesn't matter either to knight, king or God, he talk just the way he talk to anyone else. Despite his behavior, Cepot gave advise, words or even critics through his humor. The character of Cepot is philosophically described on his anatomy appearance. His wide eyes represent the nature of curiosity, alertness, enthusiasm to know the things that are still doubtful. His wide mouth represented an expression to admiration and satisfaction of a success. The distinctive character of Cepot which is funny, clever, argumentative makes the puppeteer ease to develop the story, adding some mission or campaign of innovation. In the story Cepot always be the agent of change, someone who break the awkwardness and formality. If the other Punakawan is played with the classical rhythm and song, Cepot is played with new songs, such as campursari, pasundan song, even dangdut. Cepot is the new spirit of change. It represented the innocence who tried to fight bureaucratic and rigid thought. With his satire, humor and parody, Cepot is telling the message that life does not always have to be lived with the seriousness that create stress. Life can be lived with ease, without losing direction and clung to the values and ethics of life for a better life. More of it, Cepot told us that critics do not always have to be delivered with confrontation, demonstration or anarchy. Critics can be delivered with satire and parody. The parody is the way Cepot deliver the message with easy and common language that expressive and familiar for the people. With the way Cepot talk, he can transform the formal and stiff circumstances into something familiar yet easy to understand for the audience.

Wayang golek Cepot is a performance which can transform into interactive games. It involves the puppeteer and the audience. The audience never get bored when they enjoy the performance of Cepot. This is the performance that involved the audience to think, laugh even dance.

\section{Character Design}

Designing or creating the character is important for making a mascot. Character design is a figure that determines success in delivering messages and information to the audience. Mascot is recognized for the first time from the character design as the representation from whole messages and information which need to be delivered. Its not just an actor from the story. The character is the ideological representation from the designer. It designed very well to make a better, personal relation with the audience through the visual language. Realize it or not, the character is the fundamental and a big part as an ambassador for the information and messages which is arranged from the messenger to be consume by the audience. The success of a play often determined by the character. A play is not only about an animation, comic, theatre, game or image of a product, company or city. The character design is beyond all of it. But unfortunately, sometimes it stop at the visual exploration stage, and it doesn't suit with the play or the purpose of production.

Character design has existed since a long time ago. It began at the war era, when the flags are flown and it become the differentiator between one and another. Now days character design is everywhere, when we look around, we can find it in every brand around us. The character become a symbol that have a certain value which have identification function, persuasion, even role models.

In this character design of Cepot from Sundanese wayang golek as the tourism ambassador is made through three stages. The first one is data collecting and analysis, the second stage is brainstorming, and the third stage is designing. At the first stage we don't pick Cepot to be the one we design for Bandung tourism campaign. We perform a qualitative study to select which character can representing Bandung very well. First we collect all of stories and urban legends in West Java. Than, we made list of every character in West Java. Every character on that list is equipped with a short background story. Based on the short background story we reduce the list into three choices based on the spirit of each story that match with the spirit of Bandung. From the three choices, we made studies about ideological and philosophical for each character. It is Cepot from wayang golek which match the spirit of Bandung creative city. The spirit of change of Bandung is the same with the spirit of Cepot. Besides that, Cepot is familiar in all West Java area. When the era of wayang golek in TV and live show, Cepot had a large number of fans. The show had its own prestige and always been a successful performance. When it goes live performance, it never been a quiet performance. The performance is interactive between the audience and the puppeteer. Just like a game when it's need interaction to make the show works.

The character design is strongly influenced by the culture from these characters. Every culture has variatives visual cultures with variatives ideological backgrounds. The easiest approach in recognizing the character design in every culture is to recognize how the culture affects the human, living creatures and the visual patterns. 
As mentioned in Edmund Burke Feldman's [1] theory, visual arts, in this case is designing the character of Cepot, like the other arts it has the function to affect people in certain group. It may affect the way they think, the way they feel, and even affect the way they act. In this case Cepot is designing to have a participation in visual communication education end perception to the audience through the popular design and game for Bandung tourism campaign.

To make sure there is no confusion for the people of Bandung to have Cepot for their tourism ambassador, we apply the thory from Universal Principles of Design [2], "consistency". The theory keep the design to have a consistency, it can be explored and expressed, but in the same way. So we design the character of Cepot with the same basic shape of him, but in popular way. With the same basic shape, it will form a consistency to maintain the Cepot character. So it will be easier too for the people of Bandung to know and accept Cepot instantly. The consistency will make the audience to have an emotional and positive expectation for the new design of Cepot.

Basic shape can be differentiated into three [3], there is triangle, round and square. Basic shape is important to determine the purpose. For easy example, if the inventor choose the square for the basic shape of mobility, we would not have a tire. So it is very important that basic shape have a deep meaning and important role in creating the purpose of character design. The first shape is triangle, the triangle shape give us the meaning of action, aggression, energy, sneakiness, conflict, tension. While the round shape give us different meaning. It is perceived as childs, loveable, playfullness, comforting, unity, protection. The other shape is square, it give us the meaning of stability, trust, honesty, equality.

The basic shape of Cepot is combined of square and round touch. The Square and round is picked for the message that Cepot is a trusted, honest, but comforting, playfull, and loveable.

\section{Character ExPANSION}

The character of Cepot as the ambassador of Bandung tourism campaign is designed to be consistent with the philosophical and ideological of Cepot from Sundanese wayang golek. With this new character of Cepot it can be adaptate into tourism and creative industry, but still have the local content. The character of Cepot is designed to be easy to recognize without leaving too much original identity from the wayang golek it self. The character is made with the dinamic and loveable style. With its own original character of Cepot which is homorous, and the new dynamic style of Cepot, it will be easy for the audience to accept Cepot as the Bandung tourism ambassador.

As well as the spirit of playful Cepot, it is very easy apply the character into a lot of media campaign. Such as, sticker for online message or even a Bandung tourism game board. The game board will includes the tourist attraction of Bandung. For the gimmic it can be develop into diy paper toy. The conclusion is, from the character design we can expand it into so many ways of communication and media to improve the campaign.

\section{REFERENCES}

[1] Feldman, Edmund Burke (1967)., Art as Image and Idea, New Jersey: Prentice-Hall, Inc.

[2] William Lidwell, Kritina Holden, and Jill., (2003). Universal Principles of Design. Massachusetts: Rockport Publishers, Inc.

[3] Tillman, Bryan (2011)., Creative Character Design, Kidlington: Focal Press.
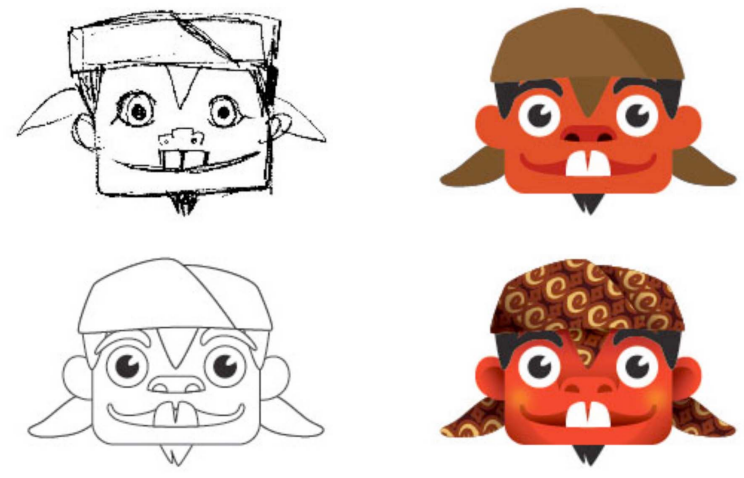

Fig. 1. Cepot character design (left), Cepot paper toy game character (right) source: Devi K. Homan

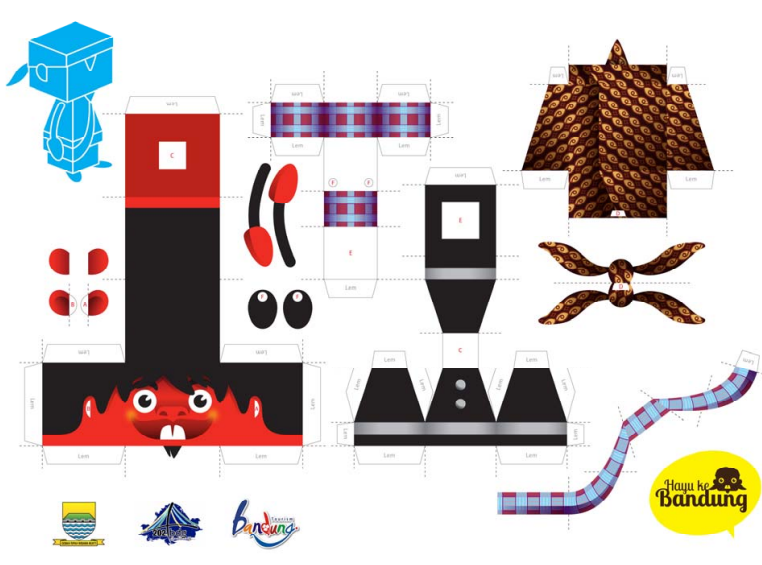

